\title{
Vibriosis and its impact on microbiological food safety
}

\author{
Victória Gabrielle PIRES MARTINS ${ }^{1}$, Janaína DOS SANTOS NASCIMENTO ${ }^{1}$, \\ Flávia Myllena DA SILVA MARTINS ${ }^{1}$, Hilana CEOTTO VIGODER ${ }^{1 *}$
}

\begin{abstract}
It is estimated that infections caused by bacteria of to the genus Vibrio are sub notified, however it is possible to notice the increase in the vibriosis incidence associated to the consumption of contaminated water and food, specially by raw seafood. Vibrio cholerae, Vibrio parahaemolyticus e Vibrio vulnificus are the main pathogenic species for humans and the infections caused by these bacteria can range from simple gastroenteritis to cases of sepsis. In Brazil, until 2020, the legislation that determined the microbial standards for food, RDC 12/2001, recommended that the presence of $V$. parahaemolyticus should be investigated in ready-to-eat food based on raw fish and similar. However, IN60, the new legislation that came into force on December 2020, no longer requires it. Since the presence of these bacteria are important risk factors for humans, as agents of diseases transmitted specially by food, it is important to monitor their presence in foods of marine origin, especially in fish and shellfish that will be consumed raw. Therefore, preventive approaches are needed, such as the control and monitoring of microbiological quality of water, mainly in high-risk food production environments (such as oysters, for example) and the microbiological control of these foods, including vibrio research.
\end{abstract}

Keywords: vibrios; vibriosis; seafood; food safety.

Practical Application: Although the studies reporting the detection of potentially pathogenic vibrios in foods in Brazil in the last decade are not numerous, it is estimated that infections caused by these bacteria are sub notified. These pathogens have been widely isolated in other countries and, in recent years, several publications have reported its presence in different types of marine foods around the world. Due to its relevance to human health, the present article discusses the main food-associated vibriosis and its impact on food safety.

\section{Introduction}

In the last decades, the world consumption of fish has shown a notable growth, favored both by the increase of its production and by the reduction of its cost. According to State of The World Fisheries and Aquaculture (Sofia), published in 2020 by the Food and Agriculture Organization of the United Nations (FAO) (Food and Agriculture Organization of the United Nations, 2020), the world consumption of fish grew on average $3.1 \%$ per year between 1961 and 2017, from the per capita consumption of $9.0 \mathrm{~kg}$, in 1961, to $20.5 \mathrm{~kg}$, in 2018 .

Consumer demand for healthier foods is among the factors that have contributed to the increased of seafood consumption, as they are rich in nutrients such as omega 3 selenium and iodine. However, it is worth noting that despite these benefits, foods of marine origin, such as fish and shellfish, are not free from microbial contamination. Among the main pathogenic bacteria that can be transmitted by this group of food are Listeria monocytogenes, Salmonella spp., Staphylococcus aureus and Vibrio spp. (Baptista et al., 2020a; Ali et al., 2020; Durmuş, 2019).

Notoriously, the increase in the world consumption of fish and seafood has been accompanied by an increase in the incidence of vibriosis in recent decades, which has been registered especially in countries where there are monitoring programs for these infectious conditions. The increased incidence of food-associated vibriosis can be noted despite it is estimated that infections caused by bacteria belonging to this microbial group are underreported (Baker-Austin et al., 2018). In the United States, for example, the annual incidence of vibriosis increased from 0.09 cases per 100,000 population, in 1996 , to 0.29 cases per 100,000 population, in 2010 (Baker-Austin et al., 2018). According to the Center for Disease Control and Prevention (CDC), 80,000 people are affected by vibriosis, with about 100 deaths annually (Center of Disease Control and Prevention, 2020).

\section{Vibrios}

The genus Vibrio is composed by 132 bacterial species (List of Prokaryotic names with Standing in Nomenclature, 2021) found in aquatic ecosystems in different regions of tropical and temperate climate throughout the world. These microorganisms can be found in their free form in estuarine and coastal water environments or in association with zooplankton, phytoplankton, algae, fish and crustaceans, from which they are frequently isolated (Trinanes \& Martinez-Urtaza, 2021).

Vibrios are Gram-negative rods, mesophilic, facultative anaerobes and, generally, mobile. Vibrio cholerae, Vibrio 
parahaemolyticus and Vibrio vulnificus are the main pathogenic species for humans and infections caused by these bacteria, vibrioses, can range from simple gastroenteritis to cases of septicemia. Such infectious conditions can be associated with both the consumption of water and contaminated food, especially by marine foods consumed raw (Ali et al., 2020).

$V$. cholerae, also known as choleric vibrio, is mainly transmitted by contaminated water. The species $V$. parahaemolyticus and V. vulnificus stand out for their prevalence among pathogens carried by food of marine origin (Baker-Austin et al., 2018).

\section{Main food-associated vibriosis}

\subsection{Cholera}

Cases of illnesses that resemble cholera have been described since antiquity. However, its etiological agent (V.cholerae) was only isolated for the first time in the late $19^{\text {th }}$ century by the German physician Robert Koch, from patients feces, and the choleric vibrio has been associated with several episodes of epidemics. Historically, cholera epidemics and pandemics are strongly correlated with inadequate sanitary conditions, overpopulation and non-treated water sources, conditions that still persist in many places around the world (Baker-Austin et al., 2018). It is estimated that between 1.3 to 4 million cases of cholera occur annually in the world, with 21,000 to 143,000 deaths (World and Health Organization, 2021).

$V$. cholerae has more than 200 serogroups, differentiated based on the chemical composition of the lipopolysaccharide (LPS) antigen present on its surface. The vast majority of cholera cases are caused by the $\mathrm{O} 1$ serotype, which has two important biological variants known as classical and El Tor biotypes. During the $19^{\text {th }}$ century, cholera spread around the world from its original reservoir in the Ganges River in India (Baker-Austin et al., 2018).

The classic biotype was responsible for the first six cholera pandemics. The seventh pandemic, still ongoing, is caused by the El Tor biotype, which remains the main causative agent of cholera worldwide. This seventh and current pandemic began in 1961 in Indonesia and quickly spread to South Asia, reaching Africa in 1971 and the Americas in 1991 (Baker-Austin et al., 2018; World and Health Organization, 2021).

Serotype O139 caused a major outbreak in 1992 in the coastal region of India and Bangladesh, spreading rapidly across Asia and starting an eighth wave of spread, but it was not considered pandemic as it was restricted to the Asian continent (World and Health Organization, 2021).

Additionally, other vibrios strains have also expanded around the globe with the emergence of potentially virulent non-O1/O139 strains has been causing concern. Non-O1 and non-O139 strains of $V$. cholerae are sporadic but serious causative agents, gastrointestinal and extra-intestinal infections, and are relatively understudied human pathogens (Vezzulli et al., 2020).

Cholera's main virulence factor is the cholera toxin, which facilitates its colonization in the intestine. The incubation period for cholera varies from 18 hours to 5 days, and symptoms can be imperceptible (asymptomatic), moderate (including vomiting, cramps and watery diarrhea) and severe (characterized by a profuse diarrhea). In the most severe cases of cholera, the individual can eliminate up to 1 liter of feces per hour, to the point where they take on the appearance of rice water, causing profound dehydration. As the diarrhea becomes more intense, rapid weight loss, muscle cramps and a comatose state ensue, in many cases, progressing to death (Center of Disease Control and Prevention, 2020; Morris, 2003).

\subsection{Infections caused by V. parahaemolyticus}

$V$. parahaemolyticus is the leading cause of diarrhea associated with seafood consumption worldwide. Infections caused by this bacterium mainly result in a mild form of diarrhea, accompanied by abdominal cramps and nausea. In addition, infection by this microorganism can produce wound infections. The onset of symptoms after consumption of contaminated food varies from 4 to 96 hours and can persist for 3 or 4 days, but this disease is usually self-limited. On rare occasions, the infection can result in septicemia that can become fatal, being more common among individuals who have pre-existing diseases. Pathogenic strains generally produce a direct thermostable hemolysin (TDH) and/or a TDH-related hemolysin (TRH), having been associated with several outbreaks, epidemics and pandemics (Li et al., 2019).

Until the 1960s, infections caused by $V$. parahaemolyticus were restricted to Japan, but from 1969 onwards, cases began to be reported in different parts of the world. In the 1970s this microorganism began to be frequently linked to small outbreaks in the USA, New Zealand, Africa, Europe and most Asian countries, becoming the main pathogen carried by seafood and a cause for health concern global public (Baker-Austin et al., 2018; Letchumanan et al., 2019).

Since 1996, the epidemiology of infections caused by $V$. parahaemolyticus has changed, following a large increase in the number of cases of gastroenteritis in Calcutta, India. Unlike most previous outbreaks, the one in Calcutta was related to a variant of the O3:K6 serotype containing the same virulence factor, the TDH toxin.

In just one year, this emerging strain has spread across Southeast Asia and is continuing to spread, having already been detected on all continents and becoming endemic in the localities it has reached. Different factors, such as climate change and ballast water from maritime transport, may be contributing to the spread of the $V$. parahaemolyticus O3:K6 strain around the world (Baker-Austin et al., 2018; Letchumanan et al., 2019).

\subsection{Infections caused by V. vulnificus}

Unlike V. cholerae and V.parahaemolyticus, V. vulnificus is an opportunistic pathogen. Infections caused by this microorganism are serious, usually require hospitalization and can be associated with both the consumption of contaminated seafood and the exposure of open wounds to sea water (Baker-Austin et al., 2018; Heng et al., 2017).

The consumption of contaminated seafood, especially mollusks, can result in conditions ranging from gastroenteritis to septicemia. Oysters are the main food associated with $V$. vulnificus 
infections, due to the large amount of these microorganisms in this product ( $\geq 10^{5}$ cells per gram) (Baker-Austin et al., 2018).

Wound infections associated with $V$. vulnificus are usually contracted during recreational activities such as swimming, fishing, and seafood handling. Dermal lesions can evolve into epithelial tissue necrosis, resulting in necrotizing fasciitis, which in some cases requires amputation of the injured limb, or can lead to sepsis in susceptible individuals, being fatal in about $25 \%$ of cases (Heng et al., 2017).

V. vulnificus strains can be classified into three biotypes, 1 , 2 or 3 , based on their biochemical characteristics. Biotype 1 is predominantly associated with cases of gastroenteritis and also most wound infections. Biotype 2, on the other hand, is rarely associated with infections in humans. Genomic comparisons suggest that biotype 3 is a hybrid of biotypes 1 and 2, which can cause serious infections in humans (including the amputation of the infected limb), however with fatality rates of less than $8 \%$ of cases (Heng et al., 2017).

V. vulnificus presents multiple virulence factors. The expression of capsular polysaccharides contributes to their evasion from the host's immune system and these microorganisms can also express exotoxins, such as Vvha and Vvpe. Vvha hemolysin facilitates the release of $\mathrm{Fe}$ ions in hemoglobin, contributing to bacterial virulence through its hemolytic and cytotoxic activity (Yuan et al., 2020). Vvpe is an extracellular metalloprotease involved in the formation of tissue necrosis, increased vascular permeability and blister formation, typical characteristics of systemic infection caused by this bacterium. Additionally, pili, OmpU and ILPA (bacterial outer membrane proteins) also contribute to the pathogenicity of this bacterium: pili are involved in cell adhesion, OmpU is able to bind to fibronectin and ILPA is a lipoprotein responsible for stimulating the immune system (Heng et al., 2017).

In immunocompromised individuals, particularly those with chronic liver disease, this bacterium can reach the bloodstream, causing septic shock, which can be fatal in 50\% of cases (Leng et al., 2019).

\section{Prevention and treatment of vibriosis}

Although it is not possible to prevent the contact of vibrio with seafood, it is possible to reduce their proliferation during transport and storage with cold. Additionally, the use of alternative strategies such as the addition of natural substrates (essential oils, bacteriocins among others), could also be used to for extension of seafood shelf-life and to inhibit foodborne pathogens (Baptista et al., 2020b; Barboza et al., 2021).

Some vaccines have been developed in order to prevent the spread of cholera, but mass vaccination of a population is a great challenge, as it involves high-cost investments for its production, distribution and storage. However, the implementation of basic sanitation, drinking water supply and measures to ensure food safety are the most effective means for preventing both cholera and other diarrheal diseases (Baker-Austin et al., 2018).

The treatment of vibrioses can vary from oral or intravenous hydration, especially in cases of cholera, to the use of antibiotics, hospitalization and amputation of infected limbs, especially in cases of necrotizing fasciitis (Baker-Austin et al., 2018; Dutta et al., 2021).

The administration of antibiotics can shorten the duration of diarrhea, in addition to reducing the transmission of their respective infectious agents. The most used antibiotics for the treatment of cholera are azithromycin, ciprofloxacin and doxycycline, also used in the treatment of infections caused by $V$. parahaemolyticus, together with quinolones. Doxycycline may also be indicated for the treatment of $V$. vulnificus, as well as third-generation cephalosporins (Dutta et al., 2021).

Similarly reported among other bacterial groups, the emergence of antimicrobial resistance in vibrios has also been increasingly common throughout the world. Genome analyzes of these microorganisms have revealed the presence of several mobile genetic elements that carry drug resistance genes, such as plasmids, transposition elements and integrons, suggesting that horizontal gene transfer is very dynamic in this group and probably is the main spreading mechanism of antimicrobial resistance among these bacteria. The spread of such resistance genes compromises the effectiveness of available antibiotics to treat these infections and poses a global threat to public health (Dutta et al., 2021).

\section{Detection of vibrios in food in Brazil}

Although bacteria of the Vibrio genus are easily destroyed by cooking, they are important risk factors for humans, as agents of diseases transmitted especially by raw foods of marine origin (Ali et al., 2020).

World Health Organization (WHO) and CDC gather global epidemiological data on these pathogens, however, few countries have surveillance systems for Vibrio spp. (Baker-Austin et al., 2018).

In Brazil, until 2020, the current legislation that specified microbiological standards for food, RDC 12/2001 (Brasil, 2001), recommended that the presence of $V$. parahaemolyticus should be investigated in ready-to-eat foods based on raw fish and similar. In the last ten years some studies have detected the presence of bacteria of the genus Vibrio in foods in different regions of the Brazilian territory (Table 1). Although most of these investigations have been mainly dedicated to isolating and identifying bacterial strains, some studies have also evaluated the pathogenic potential of the isolated microorganisms, through the detection of the virulence genes $t d h$ and $t r h$ (which encode the hemolysins TDH and TRH, respectively, from $V$. parahaemolyticus), by PCR.

In 2011, the presence of V. parahaemolyticus was investigated in samples of shrimp (Litopenaeus vannamei) sold in Natal (Rio Grande do Norte). This microorganism was detected in 10 of the 50 samples analyzed, but the virulence genes, $t d h$ and $t r h$, were not detected in any of the samples, suggesting the low potential of these strains to cause gastroenteritis (Melo et al., 2011).

Silva and collaborators detected in Florianópolis (Santa Catarina) potentially pathogenic strains of $V$. parahaemolyticus in four of 130 oyster samples in five of 215 mussel samples and 
Table 1. Isolation of Vibrio spp. from foods in Brazil.

\begin{tabular}{|c|c|c|}
\hline LOCATION (REFERENCE) & SOURCE & ISOLATED SPECIES (ISOLATION PERCENTAGE) \\
\hline \multicolumn{3}{|l|}{ South region } \\
\hline Baía Sul, SC (Ramos et al., 2012) & Oyster & V. parahaemolyticus and V. vulnificus (ND) \\
\hline \multirow[t]{2}{*}{ Florianópolis, SC (Ramos et al., 2014) } & Oyster & $\begin{array}{c}V . \text { parahaemolyticus (35\%), V. vulnificus (10\%), V. alginolyticus (7\%) } \\
\text { and V. fluvialis (2\%) }\end{array}$ \\
\hline & Mollusc farming water & $\begin{array}{c}\text { V. parahaemolyticus (45\%), V. alginolyticus (29\%) and V. vulnificus } \\
(13 \%)\end{array}$ \\
\hline \multirow[t]{2}{*}{ Florianópolis, SC (Silva et al., 2016a) } & Oyster and mussel & $V$. parahaemolyticus $(\sim 11 \%)$ \\
\hline & Shellfish farming water & V. parahaemolyticus (18\%) \\
\hline Lagoa dos Patos, RS (Rosa et al., 2016) & Fish & V. parahaemolyticus $(<1 \%)$ \\
\hline Lagoa dos Patos, RS (Rosa et al., 2017) & Fish & V.parahaemolyticus (3.3\%) \\
\hline Lagoa dos Patos, RS (Silveira et al., 2019) & Fish & Vibrio spp. (68\%) and V. vulnificus $(0.01 \%)$ \\
\hline \multicolumn{3}{|l|}{ Southeast region } \\
\hline Rio de Janeiro, RJ (Oliva et al., 2016) & Mussel & $\begin{array}{l}\text { V. parahaemolyticus (44.7\%), V. alginolyticus (19.6\%) and } V . \\
\text { vulnificus (12.4\%) }\end{array}$ \\
\hline Rio de Janeiro, RJ (Bouzas, 2021) & Mussel & V.parahaemolyticus (ND) \\
\hline Rio de Janeiro (Santos et al., 2021) & Oyster farm & V. parahaemolyticus (ND) \\
\hline \multicolumn{3}{|l|}{ Northeast region } \\
\hline $\begin{array}{c}\text { Baía de Todos os Santos, BA (Rodrigues \& } \\
\text { Carvalho, 2011) }\end{array}$ & Oyster & V. parahaemolyticus (ND) \\
\hline Natal, RN (Melo et al., 2011) & Shrimp & $V$. parahaemolyticus $(20 \%)$ \\
\hline Teresina, PI (Muratori et al., 2014) & Shrimp and farming water & V. parahaemolyticus (ND) \\
\hline Fortaleza, CE (Costa et al., 2015) & Oyster (fresh and frozen) & V. parahaemolyticus (ND) \\
\hline Salvador, BA (Silva et al., 2016b) & Water, oyster and mussel & Vibrio spp. (ND) \\
\hline Salvador, BA (Silva et al., 2018) & $\begin{array}{l}\text { Water, oyster and mussel in } \\
\text { natura }\end{array}$ & V. parahaemolyticus (66.7\%) and V. cholerae $(13.3 \%)$ \\
\hline
\end{tabular}

in five of 220 seawater samples analyzed, indicating their low incidence of less than $10 \%$ in these foods (Silva et al., 2016a).

In the coastal region of Rio de Janeiro (Rio de Janeiro), 209 strains of vibrios were isolated from mussels, being 85 (44.7\%) $V$. parahaemolyticus and 26 (12.4\%) V. vulnificus. Among the isolates identified as V. parahaemolyticus, 58 (68.2\%) had the $t d h$ gene, which encodes the TDH, but none had the trh gene, which encodes the TRH hemolysin. The virulence marker $v v H a$, which encodes the hemolysin Vvha, was found in 26 strains identified as $V$. vulnificus. The presence of these virulence genes in strains isolated from the aquatic environment indicate that this environment is a reservoir of potentially virulent strains and that may pose a risk to human health (Oliva et al., 2016).

Besides vibrio relevance, other pathogens can be transmitted by seafood and have been detected in Brazil, such as cestode and nematode larvae (Diniz et al., 2021), highlighting the need for strict quality control of these foods.

\section{Conclusions}

Although the studies reporting the detection of potentially pathogenic vibrios in foods in Brazil in the last decade are not numerous (Table 1), these pathogens have been widely isolated in other countries. In recent years, several publications have reported the presence of these bacteria in different types of marine foods around the world. Vibrios potentially pathogenic to humans were recently isolated from seafood in Germany (Vu et al., 2018), from shrimp marketed both in China (Li et al., 2020) and in Mexico (Guardiola-Avila et al., 2020), in aquaculture farms in Bangladesh (Siddique et al., 2021) and even in salads ready for consumption in Nigeria (Igbinosa et al., 2021).

Test for $V$. parahaemoliticus in ready-to-eat foods based on raw fish and similar foods used to be mandatory in Brazil (Brasil, 2001), however a new legislation, IN60 (Brasil, 2019), that came into force in $12 / 26 / 2020$, no longer requires.

Since the consumption of raw foods contaminated by Vibrio spp. can represent a risk to the health of the consumer, it is important to monitor its presence in foods of marine origin. Therefore, preventive approaches are needed, such as the control and monitoring of the microbiological quality of water, especially in high-risk food production environments (such as oysters, for example) and the microbiological control of these foods, including vibrio research.

\section{References}

Ali, A., Parisi, A., Conversano, M. C., Iannacci, A., D’Emilio, F., Mercurio, V., \& Normanno, G. (2020). Food-borne bacteria associated with seafoods: a brief review. Journal of Food Quality and Hazards Control, 7, 4-10. http://dx.doi.org/10.18502/jfqhc.7.1.2446.

Baker-Austin, C., Oliver, J. D., Alam, M., Ali, A., Waldor, M. K., Qadri, F., \& Martinez-Urtaza, J. (2018). Vibrio spp. Infections. Nature Reviews. Disease Primers, 4(1), 8. http://dx.doi.org/10.1038/s41572018-0005-8. PMid:30002421. 
Baptista, R. C., Horita, C. N., \& Sant'Ana, A. S. (2020b). Natural products with preservative properties for enhancing the microbiological safety and extending the shelf-life of seafood: a review. Food Research International, 127, 108762. http://dx.doi.org/10.1016/j. foodres.2019.108762. PMid:31882098.

Baptista, R. C., Rodrigues, H., \& Sant'ana, A. S. (2020a). Consumption, knowledge, and food safety practices of Brazilian seafood consumers. Food Research International, 132, 109084. http://dx.doi.org/10.1016/j. foodres.2020.109084. PMid:32331633.

Barboza, G. R., Almeida, J. M., \& Silva, N. C. C. (2021). Use of natural substrates as an alternative for the prevention of microbial contamination in the food industry. Food Science and Technology [Ahead of print].

Bouzas, D. (2021, January 11). Risco potencial para a segurança de alimentos: Vibrio parahaemolyticus isolado de mexilhões no Rio de Janeiro. Food Safety Brazil. Retrieved from: https:// foodsafetybrazil.org/risco-potencial-para-seguranca-de-alimentosvibrio-parahaemolyticus-isolado-de-mexilhoes-no-rio-de-janeiro/

Brasil, Agência Nacional de Vigilância Sanitária - ANVISA. (2001, January 2). Resolução da diretoria colegiada- RDC no 12 de 02 de janeiro de 2001. Diário Oficial da União. Retrieved from: http:// portal.anvisa.gov.br/documents/33880/2568070/RDC_12_2001. pdf/15ffddf6-3767-4527-bfac-740a0400829b

Brasil, Agência Nacional de Vigilância Sanitária - ANVISA. (2019, December 23). Instrução Normativa - IN n ${ }^{\circ} 60$ de 23 de dezembro de 2019. Diário Oficial da União. Retrieved from: https://bvsms. saude.gov.br/bvs/saudelegis/anvisa/2019/IN_60_2019_COMP.pdf

Center of Disease Control and Prevention - CDC. (2020). Cholera Vibrio cholerae infection. Illness and symptoms. Retrieved from: https://www.cdc.gov/cholera/illness.html

Costa, R. A., Araújo, R. L., \& Vieira, R. H. S. F. (2015). Raw tropical oysters as vehicles for multidrug-resistant Vibrio parahaemolyticus. Revista do Instituto de Medicina Tropical de Sao Paulo, 57(3), 193-196. http:// dx.doi.org/10.1590/S0036-46652015000300002. PMid:26200957.

Diniz, J. B., Knoff, M., Fonseca, M. C. G., Gomes, D. C., \& Clemente, S. C. (2021). Cestode and nematode larvae of hygienic-sanitary importance parasitizing Percophis brasiliensis (Actinopterygii) collected from fish markets of the municipality of Niterói, RJ, Brazil. Food Science and Technology [Ahead of print].

Durmuş, M. (2019). Fish oil for human health: omega-3 fatty acid profiles of marine seafood species. Food Science and Technology, 39(Suppl 2), 454-461. http://dx.doi.org/10.1590/fst.21318.

Dutta, D., Kaushik, A., Kumar, D., \& Bag, S. (2021). Foodborne pathogenic vibrios: antimicrobial resistance. Frontiers in Microbiology, 12, 638331. http://dx.doi.org/10.3389/fmicb.2021.638331. PMid:34276582.

Food and Agriculture Organization of the United Nations - FAO. (2020). State of The World Fisheries and Aquaculture (SOFIA, 2020) - Sustainability in action. Rome: FAO.

Guardiola-Avila, I., Martínez-Vázquez, K. I., Juárez-Rendón, M., Alvarez-Ainza, A., Paz-González, P., \& Rivera, G. (2020). Prevalence and virulence of Vibrio species isolated from raw shrimp from retail markets in Reynosa, Mexico. Letters in Applied Microbiology, 71(3), 280-286. http://dx.doi.org/10.1111/lam.13315. PMid:32408383.

Heng, S., Letchumanan, V., Deng, C., Mutalib, N. A., Khan, T. M., Chuah, L., Chan, K., Goh, B., Pusparajah, P., \& Lee, L. (2017). Vibrio vulnificus: an environmental clinical burden. Frontiers in Microbiology, 8, 997. http://dx.doi.org/10.3389/fmicb.2017.00997. PMid:28620366.

Igbinosa, E. O., Beshiru, A., Igbinosa, I. H., Ogofure, A. G., \& Uwhuba, K. E. (2021). Prevalence and characterization of food-borne Vibrio parahaemolyticus from african salad in Southern Nigeria. Frontiers in Microbiology, 12, 632266. http://dx.doi.org/10.3389/fmicb.2021.632266. PMid:34168622.

Leng, F., Lin, S., Wu, W., Zhang, J., Song, J., \& Zhong, M. (2019). Epidemiology, pathogenetic mechanism, clinical characteristics, and treatment of Vibrio vulnificus infection: a case report and literature review. European Journal of Clinical Microbiology \& Infectious Diseases, 38(11), 1999-2004. http://dx.doi.org/10.1007/ s10096-019-03629-5. PMid:31325061.

Letchumanan, V., Loo, K., Law, J. W., Wong, S. H., Goh, B., Mutalib, N. S., \& Lee, L. H. (2019). Vibrio parahaemolyticus: the protagonist of foodborne diseases. Progress in Microbes and Molecular Biology, 2(1), a0000029. http://dx.doi.org/10.36877/pmmb.a0000029.

Li, L., Meng, H., Gu, D., Li, Y., \& Jia, M. (2019). Molecular mechanisms of Vibrio parahaemolyticus pathogenesis. Microbiological Research, 222, 43-51.http://dx.doi.org/10.1016/j.micres.2019.03.003. PMid:30928029.

Li, Y., Xie, T., Pang, R., Wu, Q., Zhang, J., Lei, T., Xue, L., Wu, H., Wang, J., Ding, Y., Chen, M., Wu, S., Zeng, H., Zhang, Y., \& Wei, W. (2020). Food-Borne Vibrio parahaemolyticus in China: prevalence, antibiotic susceptibility, and genetic characterization. Frontiers in Microbiology, 11, 1670. http://dx.doi.org/10.3389/fmicb.2020.01670. PMid:32765472.

List of Prokaryotic names with Standing in Nomenclature - LPSN. (2021). Genus Vibrio. Retrieved from: https://lpsn.dsmz.de/genus/vibrio

Melo, L. M. R., Almeida, D., Hofer, E., Reis, C. M. F., Theophilo, G. N. D., Santos, A. F. M., \& Vieira, R. H. S. F. (2011). Antibiotic resistance of Vibrio parahaemolyticus isolated from pond-reared Litopenaeus vannamei marketed in Natal, Brazil. Brazilian Journal of Microbiology, 42(4), 1463-1469. http://dx.doi.org/10.1590/S151783822011000400032. PMid:24031779.

Morris, J. G. Jr. (2003). Cholera and other types of vibriosis: a story of human pandemics and oysters on the half shell. Clinical Infectious Diseases, 37(2), 272-280. http://dx.doi.org/10.1086/375600. PMid:12856219.

Muratori, M. C. S., Veloso, A. P. B., Costa, A. P. R., Pereira, M. M. G., Guimarães, C. M. M., Calvet, R. M., Santos, Y. F. M., \& Cardoso Filho, F. C. (2014). Vibrio parahaemolyticus em carcinicultura marinha. Revista Brasileira de Saúde e Produção Animal, 15(2), 289-296. http:// dx.doi.org/10.1590/S1519-99402014000200006.

Oliva, M. S., Bronzato, G. F., Soares, L. C., Pereira, I. A., Pribul, B. R., Souza, M. A. S., Coelho, S. M. O., Coelho, I. S., Rodrigues, D. P., \& Souza, M. M. S. (2016). Detection of virulence and antibiotic resistance genes in environmental strains of Vibrio spp. from mussels along the coast of Rio de Janeiro State, Brazil. African Journal of Microbiological Research, 10(24), 906-913. http://dx.doi.org/10.5897/ AJMR2015.7636.

Ramos, R. J., Miotto, L. A., Miotto, M., Silveira, N. Jr, Cirolini, A., Silva, H. S., Rodrigues, D. P., \& Vieira, C. R. W. (2014). Occurrence of potentially pathogenic Vibrio in oysters (Crassostrea gigas) and waters from bivalve mollusk cultivations in the South Bay of Santa Catarina. Revista da Sociedade Brasileira de Medicina Tropical, 47(3), 327-333. http://dx.doi.org/10.1590/0037-8682-0069-2014. PMid:25075484.

Ramos, R. J., Pereira, M. A., Miotto, L. A., Faria, R. D. A., Silveira, N. Jr, \& Vieira, C. R. W. (2012). Ocurrence of Vibrio spp., positive coagulase staphylococci and enteric bacteria in oysters (Crassostrea gigas) harvested in the south bay of Santa Catarina island, Brazil. Food Science and Technology, 32(3), 478-484. http://dx.doi.org/10.1590/ S0101-20612012005000061.

Rodrigues, L. A. P., \& Carvalho, C. D. Fo. (2011). Occurrence of Vibrio parahaemolitycus in stages of oysters improvement (Crassostera rhizophorae), cultivated in the Baia de Todos os Santos-BA, and 
determination of the critical control points. UNOPAR Cientifica. Ciências Biológicas e da Saúde, 13(2), 77-83.

Rosa, J. V., Käefer, K., Conceição, N. V., Conceição, R. C. S., \& Timm, C. D. (2017). Formação de biofilme por Vibrio parahaemolyticus isolados de pescados. Pesquisa Veterinária Brasileira, 37(4), 339-345. http://dx.doi.org/10.1590/s0100-736x2017000400007.

Rosa, J. V., Silva, C. J., Barbosa, F., Bairros, J., Duval, E. H., Helbig, E., \& Timm, C. D. (2016). Vibrio parahaemolyticus and Salmonella enterica isolates in fish species captured from the Lagoa dos Patos estuary. Semina: Ciências Agrárias, Londrina, 37(3), 1345-1354.

Santos, L. O., Lanna, C. A., Arcanjo, A. C. A., Bisch, P. M., \& Von Krüger, W. M. A. (2021). Genotypic diversity and pathogenic potential of clinical and environmental Vibrio parahaemolyticus isolates from Brazil. Frontiers in Microbiology, 12, 602653. http://dx.doi.org/10.3389/ fmicb.2021.602653. PMid:33776949.

Siddique, A. B., Moniruzzaman, M., Ali, S., Dewan, N., Islam, M. R., Islam, S., Amin, M. B., Mondal, D., Parvez, A. K., \& Mahmud, Z. H. (2021). Characterization of pathogenic Vibrio parahaemolyticus isolated from fish aquaculture of the Southwest coastal area of Bangladesh. Frontiers in Microbiology, 12, 635539. http://dx.doi.org/10.3389/ fmicb.2021.635539. PMid:33763050.

Silva, H. S., Medeiros, K., Miotto, M., Barreta, C., \& Vieira, C. R. W. (2016a). Occurrence of Vibrio parahaemolyticus in oysters (Crassostrea gigas) and mussels (Perna perna) of the seacoast of Santa Catarina, Brazil. African Journal of Microbiological Research, 10(33), 13221327. http://dx.doi.org/10.5897/AJMR2015.7873.

Silva, I. P., Carneiro, C. S., Saraiva, M. A. F., Oliveira, T. A. S., Sousa, O. V., \& Evangelista-Barreto, N. S. (2018). Antimicrobial resistance and potential virulence of Vibrio parahaemolyticus isolated from water and bivalve mollusks from Bahia, Brazil. Marine Pollution Bulletin,
131(Pt A), 757-762. http://dx.doi.org/10.1016/j.marpolbul.2018.05.007. PMid:29887003.

Silva, I. P., Sousa, O. V., Saraiva, M. A. F., \& Evangelista-Barreto, N. S. (2016b). Vibrio cholerae non-O1 in bivalve mollusks harvesting area in Bahia, Brazil. African Journal of Microbiological Research, 10(26), 1005-1010. http://dx.doi.org/10.5897/AJMR2015.7889.

Silveira, D. R., Rosa, J. V., Kaefer, K., Bach, L. G., Barbosa, A. O., \& Timm, C. D. (2019). Ability of Vibrio vulnificus isolated from fish of the Lagoa dos Patos estuary in south Brazil to form biofilms after sublethal stress and bacterial resistance to antibiotics and sanitizers. International Journal of Food Microbiology, 303, 19-25. http://dx.doi. org/10.1016/j.ijfoodmicro.2019.05.007. PMid:31112793.

Trinanes, J., \& Martinez-Urtaza, J. (2021). Future scenarios of risk of Vibrio infections in a warming planet: a global mapping study. The Lancet, 5(7), e426-e435. http://dx.doi.org/10.1016/S25425196(21)00169-8. PMid:34245713.

Vezzulli, L., Baker-Austin, C., Kirschner, A., Pruzzo, C., \& MartinezUrtaza, J. (2020). Global emergence of environmental non-O1/O139 Vibrio cholerae infections linked with climate change: a neglected research field? Environmental Microbiology, 22(10), 4342-4355. http:// dx.doi.org/10.1111/1462-2920.15040. PMid:32337781.

Vu, T. T. T., Alter, T., \& Huehn, S. (2018). Prevalence of Vibrio spp. in retail seafood in Berlin, Germany. Journal of Food Protection, 81(4), 593-597. http://dx.doi.org/10.4315/0362-028X.JFP-17-366. PMid:29517352.

World and Health Organization - WHO. (2021). Cholera. Retrieved from: https://www.who.int/news-room/fact-sheets/detail/cholera

Yuan, Y., Feng, Z., \& Wang, J. (2020). Vibrio vulnificus hemolysin: biological activity, regulation of $v v h A$ expression, and role in pathogenesis. Frontiers in Immunology, 11, 599439. http://dx.doi. org/10.3389/fimmu.2020.599439. PMid:33193453. 